\title{
TABULATE CORALS AND STRATIGRAPHY OF LOWER DEVONIAN AND MISSISSIPPIAN ROCKS NEAR BARCELONA (CATALONIAN COASTAL RANGES, NORTHEAST SPAIN)
}

Trabajo presentado a las

XXII Jornadas de la Sociedad Española de Paleontología.

Universidad de León

León, 28-30 de Septiembre de 2006

\author{
Yves PLUSQUELLEC ${ }^{1}$, Esperanza FERNÁNDEZ- \\ MARTÍNEZ ${ }^{2}$, Javier SANZ LÓPEZ ${ }^{3}$, Francisco \\ SOTO ${ }^{4}$, Josep MAGRANS 5 and Enric FERRER 6
}

\footnotetext{
${ }^{1}$ UMR 6538 Domaines océaniques, Laboratoire de Paléontologie, Faculté des Sciences, Université de Bretagne Occidentale. 6, Av. Le Gorgeu- C.S. 93837, 29238 Brest Cedex 3, Francia. Yves.Plusquellec@univ-brest.fr

${ }^{2}$ Área de Paleontología. Facultad de Ciencias Biológicas y Ambientales. Campus de Vegazana, s/n. 24071 León. e.fernandez@unileon.es

${ }^{3}$ Facultade de Ciencias da Educación, Universidade da Coruña. Campus de Elviña, s/n. 15071 A Coruña. jasanz@udc.es

${ }^{4}$ Departamento de Geología, Universidad de Oviedo. C/ Jesús Arias de Velasco, s/n.33005 Oviedo.fsoto@geol.uniovi.es

${ }^{5} \mathrm{C} /$ Aragó, 24. 08859 Begues (Barcelona).

${ }^{6}$ C/ Lluís Solé Sabarís 31-B. 08850 Gavà (Barcelona).

enricdegava@eresmas.com
}

Plusquellec, Y., Fernández-Martínez, E., Sanz López, J., Soto, F., Magrans, J. \& Ferrer, E. 2007. Tabulate corals and stratigraphy of Lower Devonian and Mississippian rocks near Barcelona (Catalonian Coastal Ranges, Northeast Spain). [Corales tabulados y estratigrafía del Devónico Inferior y del Misisípico en las inmediaciones de Barcelona (Cordilleras Costeras Catalanas, nordeste de España).] Revista Española de Paleontología, 22 (2), 175-192. ISSN 0213-6937.

\begin{abstract}
In this paper the content of tabulate corals of the Olorda (Lower Devonian) and El Papiol (Mississipian) Formations near Barcelona (Catalonian Coastal Ranges, NE Spain) are described for the first time. The Olorda Formation was studied in the Bruguers section, where two new tabulate coral species, Petridictyum casanovai n. sp. and Procteria (Granulidictyum)? gavaensis n. sp., have been collected. The El Papiol Formation was studied in the El Papiol and Cánoves sections, and four tabulate coral taxa, Sutherlandia? sp., Smythina humilis (Hinde, 1896), Palaeacis sp. and Cladochonus sp., have been recognised. In addition, the succession of the Olorda Formation in Bruguers is described. Lochkovian-lowermost Pragian age is established for the B Member of this formation in Bruguers and this section is correlated with the type section of the formation in Santa Creu d'Olorda. Finally, it is deduced that the sedimentation of the upper part (B Member) of the Olorda Formation, in Bruguers, and the El Papiol Formation, in the El Papiol, took place on a muddy and soft bottom, typical of still waters, with scarce terrigenous supplies.
\end{abstract}

Key words: Tabulata, Systematics, Devonian, Carboniferous, Stratigraphy, Catalonian Coastal Ranges (NE Spain).

\section{RESUMEN}

En el presente trabajo se describe por primera vez el contenido en corales tabulados de las Formaciones Olorda (Devónico Inferior) y El Papiol (Misisípico) en las inmediaciones de Barcelona (Cadenas Costeras Catalanas, NE de España). La Formación Olorda fue estudiada en la sección de Bruguers, donde se han recolectado dos nuevas especies de corales tabulados, Petridictyum casanovai n. sp. y Procteria (Granulidictyun)? gavaensis n. sp. La Formación El Papiol fue estudiada en las secciones de El Papiol y Cánoves, y en ella han sido reconocidos cuatro taxones de corales tabulados, Sutherlandia? sp., Smythina humilis (Hinde, 1896), Palaeacis sp. y Cladochonus sp. Adicionalmente, se describe la sucesión de la Formación Olorda en la localidad de Bruguers, se establece una edad Lochkoviense-Praguiense basal para el Miembro B de dicha formación, y se correlaciona esta 
sección con la sección tipo de la formación (Santa Creu d'Olorda). Finalmente, se deduce que la sedimentación de la parte superior (Miembro B) de la Formación Olorda, en Bruguers, y la Formación El Papiol, en El Papiol, tuvo lugar sobre un fondo blando y barroso, propio de aguas tranquilas, con escasos aportes terrígenos.

Palabras clave: Tabulados, Sistemática, Devónico, Carbonífero, Estratigrafía, Cordilleras Costeras Catalanas (NE de España).

\section{INTRODUCTION}

The Variscan rocks of the Catalonian Coastal Ranges (NE Spain) are comprised of Palaeozoic metasediments, metavolcanic rocks and abundant post-metamorphic granitic intrusive bodies (Fig. 1). They are outcropping, ranging NE-SW within the horst structures generated by Neogene tensional tectonics. The Palaeozoic stratigraphic sequence of the Catalonian Coastal Ranges is not very well known (Julivert \& Durán, 1990). It constitutes the marginal but basic referent for the Palaeozoic succession in the eastern part of the Tertiary Ebro basin in the Iberian Peninsula.

The first studies on Devonian and Carboniferous rocks are old and correspond to Almera (1891, 1898a, b) and Barrois (1892, 1893). Later, Greiling \& Puschmann (1965) and Puschmann (1968a, b) established stratigraphic units on the northern part of the Catalonian Coastal Ranges, but a formal stratigraphy has more recently been established by Julivert et al. $(1986,1987)$ and Martínez Chacón et al. (2003). Studies on the fossil content of these rocks are usually local and restricted by poor preservation of the specimens in the metasediments. However, studies on any fossil remains are important for the adquisition of an acceptable level of knowledge of local development of Palaeozoic life, and this is equally the case for the tabulata corals described in the present paper.

The coral bearing beds studied correspond to different outcrops located several kilometres from Barcelona city. Some of them come from Devonian and others from Carboniferous shales, in the condensed upper Palaeozoic se-
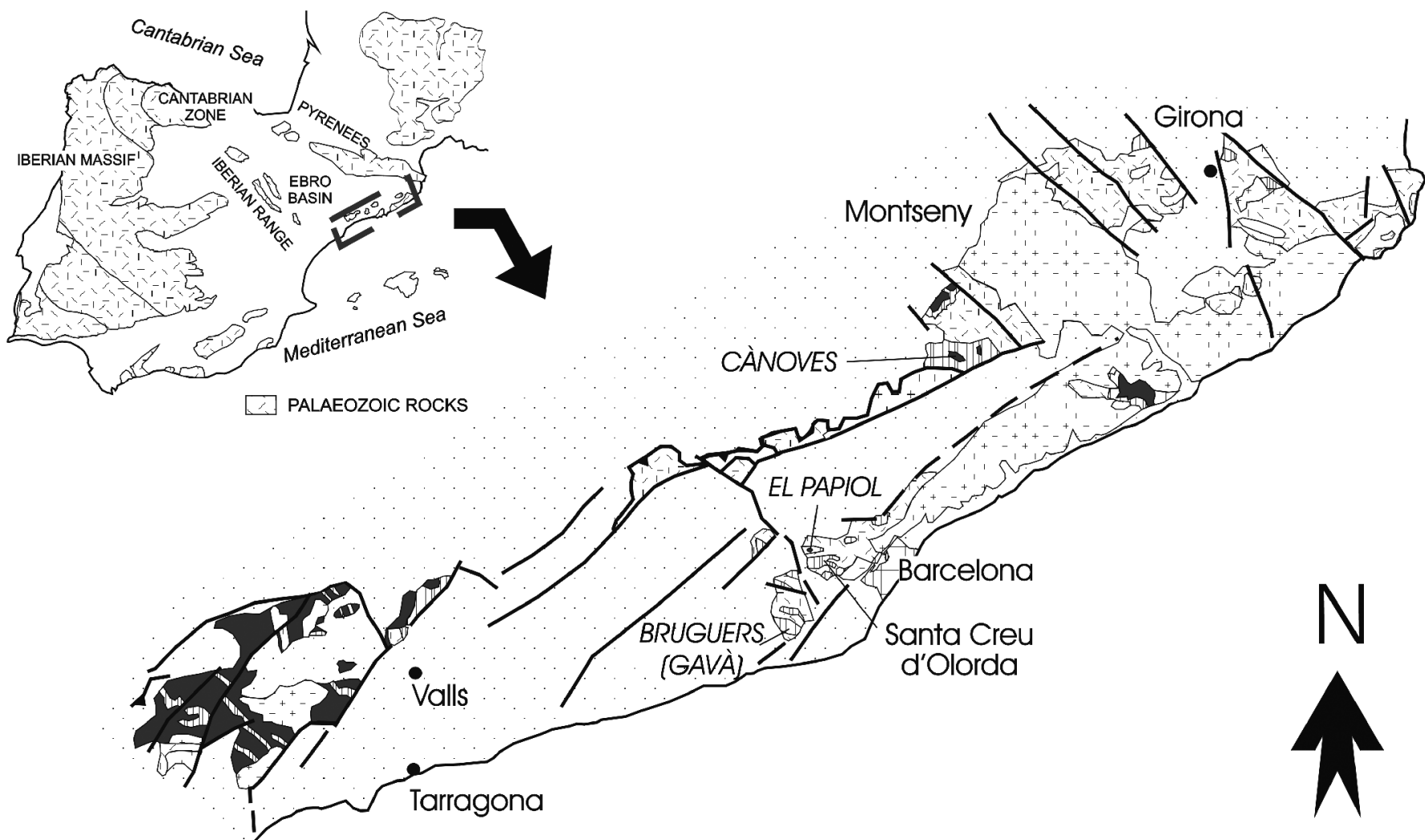

0

$25 \mathrm{~km}$

Post-Palaeozoic

Figure 1. Geological sketch of the Catalonian Coastal Ranges, showing studied coral localities and Santa Creu d'Olorda quarries. 
quence of the Catalonian Coastal Ranges, where MiddleUpper Devonian rocks are usually absent. Hence, middle Tournaisian cherts are usually above Emsian or older beds. Old identifications of corals correspond to the presence of the tabulate Pleurodictyum selcanum Giebel, 1858, and the rugose Zaphrentis n. sp., after Barrois (1892) and Almera (1898a) from the Lower Devonian at Can Amigonet (El Papiol). Later, Almera (1900) reported Petraia sp., and Schriel (1929) Zaphrentis guillieri Barrois, 1892. The studied specimens were collected by two of the authors (J. Magrans \& E. Ferrer, together with R. Mañé) between the years 1980 to 1986 and occasionally until 1990 .

\section{GEOLOGICAL AND STRATIGRAPHICAL SETTING}

\section{LOWER DEVONIAN ROCKS Bruguers section}

The samples studied come from beds which were included in the "Tentaculiten-Schiefer" by Puschmann (1968a), later formally named the Olorda Formation by Julivert et al. (1986). The type section of this formation was described at the Santa Creu d'Olorda quarries, just west of Barcelona city, but the rocks described here come from another section which outcrops at Bruguers hermitage, an area with isolated houses (Ramoneda housing) on the small mountains between the Gavà and the Begues villages (Fig. 1).

The stratigraphic section of Bruguers is not well known. The rocks constitute a discontinous succession folded and cut by numerous faults. Shales show slaty cleaveage, and secondary dolostones, sometimes ankerites, replace many limestone beds. In spite of the faults, a study of the fossil content allows the authors to propose a composite section (Fig. 2). A section of $37 \mathrm{~m}$ of shales was measured at Bruguers (Chlupáč et al., 1997) and correlated with the A Member of the Olorda Formation in its type section. It forms part of an inverse flank cut by several detachment faults and thrusted by the Silurian limestones ( $\mathrm{La} \mathrm{Creu}$ Formation of Julivert et al., 1986).

Member A in the Bruguers section begins with more than $5.5 \mathrm{~m}$ of black shales corresponding to the Scyphocrinites beds. It yielded graptolites which are probably uppermost Silurian, well-known lowermost Lochkovian graptolites, together with scarce molluscs, eurypterids, trilobites and conodonts (H. Jaeger, pers. com. 1987 and 1989; Ferrer et al., 1992; Chlupáč et al., 1997; GutiérrezMarco et al., 1999). On top of these beds new black shales appear which include fine-grained sandstone and thin beds of chert, and chert and phosphate nodules. The upper part of this A Member (the last $9.5 \mathrm{~m}$ ) is composed of green and red coloured carbonate shales with rare black shale horizons. Occasionally, beds with trilobites, brachiopods, phyllocarids and eurypterids can include upper Lochkovian graptolites of the Monograptus hercynicus Zone. Dacryoconarids and poorly preserved corals were observed in the final metres.

The base of Member B in the Bruguers section is represented by grey-greenish carbonate shales becoming yellow when they have been weathered, and which include scarce and thin carbonate beds. In this section, the B Member is mainly constituted by shales with some carbonate beds. The thickness of this could be between 5 and $8 \mathrm{~m}$ (accurate measurement has not been possible), and it contains some layers of shales which have yielded dacryoconarids, brachiopods, trilobites, bivalves, orthoconic cephalopods, ostracodes, phyllocarids and scarce casts of conodonts.

Above the Member B, a unit composed of nodular carbonate beds with marls can be correlated with the C Member of the Olorda Formation at Santa Creu d'Olorda.

The fauna studied in this paper comes from a few metres of grey-greenish carbonate shales of the B Member at the outcrop 4beta (Fig. 2), located on a small margin of a track. Samples from 4Runes probably correspond to loose specimens from the same beds piled up near the outcrop 4beta. This outcrop is located about 120 m northwest of outcrop 5 from Racheboeuf et al. (1993), with brachiopods and dacryoconarids.

Age of the Olorda Formation in the Bruguers section

Racheboeuf et al. (1993) described Lochkovian brachiopods with Bohemian affinity from the outcrop 5 (shales among limestones). Alberti (1993: 97) indicated latest Lochkovian or earliest Pragian age, for the samples collected by two of the authors (J. Magrans \& E. Ferrer, together with R. Mañé) in marls from the outcrop 4beta. This dating is based on the presence of the dacryoconarids Paranowakia geinitziana (Richter, 1854), Paranowakia intermedia (Barrande, 1867) and Nowakia kabylica Alberti, 1980 (= N. sororcula Lukes, 1982). Furthermore, Nowakia cf. acuaria (Richter, 1854) is also present (G.K.B. Alberti, pers. com. 1990). Paranowakia intermedia is a Lochkovian taxon. Nowakia kabylica is an auxiliary indicator for the basal Pragian in Bohemia, because the Lochkovian-Pragian boundary falls within the range of this species (Chlupáč, 1995). However, the entry of Nowakia kabylica occurs in the basal Pragian, while Paranowakia geinitziana disappears just at the bed located above the Lochkovian-Pragian boundary at the GSSP (Chlupáč \& Oliver, 1989). Consequently, the upper part of the B Member in the Bruguers section could be correlated with the basal Pragian.

The late Lochkovian to earliest Pragian age is partly confirmed by the trilobites also identified by Alberti (1993) and figured in Magrans \& Ferrer (2006). In spite of the open nomenclature of the identified taxa [Prokops $\mathrm{n}$. sp., Lochkovella n. sp., "Deckmannites" n. sp., Cheirurus (Pilletopeltis) sp. gr. cordai (Barrande, 1852), Reedops n. sp., Eopiniproteus n. sp., Prodevermannia? n. sp., Leonaspis sp. and Harpes sp.], Lochkovella is a genus reported from 


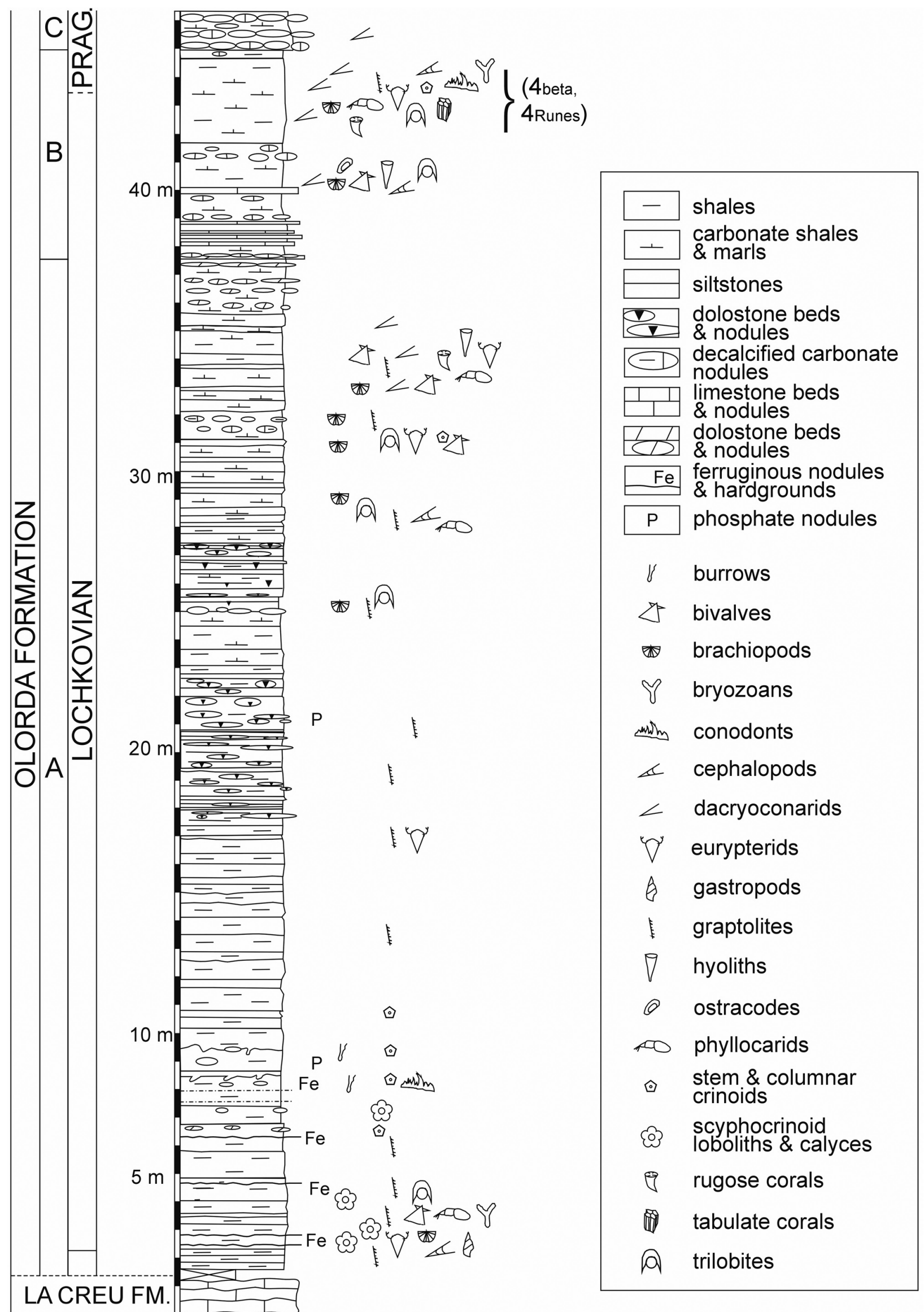

Figure 2. Composite stratigraphic section of the Lochkovian and lower Pragian rocks at the northern outcrops of Bruguers area. 
the Lochkovian of Bohemia, while Reedops is a Pragian genus (Chlupáč, 1995; Chlupáč \& Oliver, 1989).

Alberti (1993) also identified Nowakia acuaria (Richter, 1854) in the lower beds of C Member in the Bruguers section, indicating a Pragian age for these levels.
Correlation of the Bruguers section with the type section of Santa Creu d'Olorda

There are lithological and age differences between the B Member of the Olorda Formation in its type section (Santa Creu d'Olorda) and the Bruguers section studied (Fig. 3).

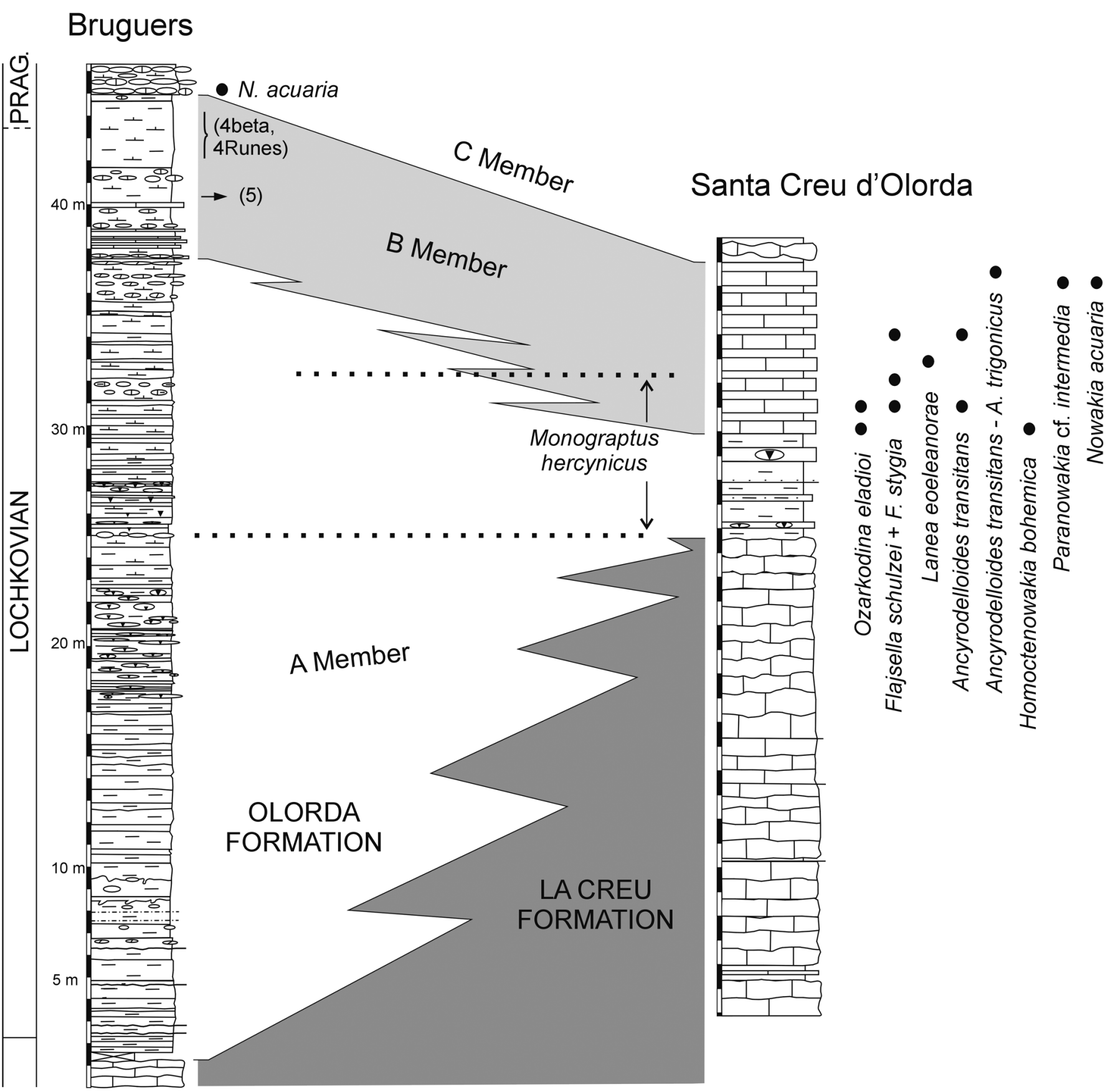

Figure 3. Correlation between the composite sections of Bruguers and Santa Creu d'Olorda. The range of Monograptus hecynicus, the probable location of the outcrop 5 of Racheboeuf et al. (1993), the location of the studied outcrops 4beta and 4Runes and the finding of the dacryoconarid Nowakia acuaria are indicated from the Bruguers section. The range of M. hecynicus after Julivert et al. (1985), the finding of conodonts and dacryoconarids (Homoctenowakia bohemica, Paranowakia cf. intermedia and N. acuaria) after García-López et al. (1990) and Valenzuela-Ríos \& García-López (1998) are shown at the Santa Creu d'Olorda section. 
In Santa Creu d'Olorda, the B Member is constituted by 4-5 $\mathrm{m}$ of yellow limestones, containing abundant dacryoconarids, and interbedded thin red shale beds. The lower beds of the member yielded graptolite Monograptus hercynicus Perner, 1899 (Julivert et al., 1985), together with dacryoconarid Homoctenowakia bohemica (Bouček, 1964) (see Alberti, 1980, 1993; García-López et al., 1990). Conodonts (García-López et al., 1990; Valenzuela-Ríos \& García-López, 1998) from the same lower part [Ancyrodelloides transitans (Bischoff \& Sannemann, 1958), together with Flajsella schulzei (Bardashev, 1989) and F. stygia (Flajs, 1967)] were correlated to the upper part of the $A n$ cyrodelloides transitans Interval (L. eleanorae-A. trigonicus Zone of Valenzuela-Ríos \& Murphy, 1997). Above and towards the top, a transitional element between A. transitans and A. trigonicus Bischoff \& Sannemann, 1958, was assigned as probably belonging to the basal part of the trigonicus Interval (Valenzuela-Ríos \& García-López, 1998; A. trigonicus-C. pandora Zone of Valenzuela-Ríos \& Murphy, 1997), middle Lochkovian in age. Moreover, the presence of dacryoconarids Paranowakia cf. intermedia (Barrande, 1867) and Nowakia acuaria, just below the last conodont found (near the top of the B Member at Santa Creu d'Olorda), was correlated with the $N$. sororcula Zone (=N. kabylica Zone) by García-López et al. (1990) near the Lochkovian-Pragian boundary.

Thus, the lower part of the B member of the Olorda Formation seems to be older in age at the Santa Creu d'Olorda quarries than in the section studied in Bruguers. A facies change between the upper part of the A Member of the studied Bruguers section and the lower part of the B Member in the Santa Creu d'Olorda quarries is interpreted (Fig. 3).

The chronostratigraphic Lochkovian-Pragian boundary in Bohemia is marked by a relatively strong faunal turnover and it is located slightly below a marked colour change of the carbonate rocks, from dark to light (Chlupáč \& Kukal, 1986). Such a lithologic change has been interpreted in different Devonian basins of the world (Chlupáč \& Kukal, $o p$. cit.) as indicating a fairly rapid but not very significant lowering of the sea-level (Lochkovian-Pragian Event). In the Bruguers section such an event is located in the lithologic change between the B and C Members.

\section{MISSISSIPPIAN ROCKS}

The Carboniferous corals were collected in three outcrops (Cànoves, El Papiol 1 and El Papiol 3; Fig. 4) of the El Papiol Formation (Martínez Chacón et al., 2003). El Papiol Formation is composed of 5 to $10 \mathrm{~m}$ of shales and marls with limestone beds in the lower part. A detailed stratigraphy can be found in Martínez Chacón et al. (2003), who described the brachiopod association from El Papiol Formation. The Cànoves outcrop (Fig. 4, CA1) corresponds to beds below and above the uppermost carbonate bed at the Cànoves section. El Papiol 1 outctrop (Fig.
4, EP1) is located in the upper part of the lower member, at the entrance to the Can Puig house (El Papiol). The location of this outcrop by Martínez Chacón et al. (2003) was incorrect, because the location of the outcrop EP2 was changed in the text, but not in the picture (MartínezChacon et al., 2003: Fig. 2). These beds are Visean in age, probably upper Visean, because Gandl (in Anadón et al., 1985) reported conodonts from the Gnathodus bilineatus Zone (Belgian Visean V3b beta) at the Montseny massif. The El Papiol 3 outcrop (Fig. 4, EP3) corresponds to the upper part of the El Papiol Formation at the El Papiol section, containing abundant crinoids, brachiopods, bivalves, trilobites, gastropods, small rugose and tabulate corals. An ammonoid (Dombarites sp.) indicating a latest Visean or early Serpukhovian age was also found (Kullmann et al., 2001). A noticeable bed bearing abundant corals with a thorny morphology occurs $20 \mathrm{~cm}$ below the strata with Dombarites sp.

\section{SEDIMENTOLOGICAL REMARKS}

The Lower Devonian corals occur occasionally in the upper part of the A Member and in the B Member of the Olorda Formation (upper Lochkovian to basal Pragian). The sedimentation for this part of the succession took place on muddy and soft bottoms in still waters and scarce terrigenous supplies. The fauna shows low diversity and is abundant only in some layers, where the conditions for invertebrate colonization and preservation were favourable. Brachiopods are small and thin shelled. They were considered by Racheboeuf et al. (1993) to be components of an open shelf environment in the Benthic Assemblage 4 to 5 of Boucot (1975). Racheboeuf et al. (1993) also stressed their Bohemian affinity. However, the abundance of dacryoconarids, trilobites, and other fossil groups, seems to be indicative of better environmental conditions (at least episodic) than those corresponding to the lower part of the Member A. In this sense, the prevailing pelagic scyphocrinoid, graptolite and eurypterid remains from the lower part correspond to an anoxic environment, particularly at the sea-bottom. A progressive increase in the number of fossiliferous layers and in the diversity of the associations is noticeable from the entry of $M$. hercynicus.

Conditions similar to the Member B are described for the Mississippian El Papiol Formation. Brachiopods are small and thin shelled. According to Martínez Chacón et al. (2003) they lived in still waters and in a muddy and soft bottom. Specimens of the genus Parmephrix usually lived attached to hard clasts or shells. The sedimentation of the B Member took place on a deep outer ramp between deposits of carbonates of the lower member of the El Papiol Formation and the first silicilastic supplies of the Fm. Cànoves (Culm Facies). Fauna-bearing beds are interpreted as condensed horizons or also as occasional episodes during favourable conditions for life at the bottom (Martínez Chacón et al., 2003). 


\section{MATERIAL}

The studied specimens are deposited at the "Museu Geològic del Seminari de Barcelona” (Barcelona, Catalonia, Spain), catalogue number MGSB 73907-73922. Additional specimens from Ossa-Morena Zone are deposited in the "Collections de Paléontologie, Faculté des Sciences et Techniques, Université de Bretagne Occidentale", (Brest, France), catalogue number LPB 15205 and 15206.

\section{SYSTEMATICS}

Subclass TABULATA Milne-Edwards \& Haime, 1850 Order FAVOSITIDA Wedekind, 1937

Family Micheliniidae Waagen \& Wentzel, 1886

Subfamily Micheliniinae Waagen \& Wentzel, 1886

Genus Petridictyum Schindewolf, 1959

Type-species: Pleurodictyum petrii Maurer, 1874
Diagnosis: see Hill (1981: F565). Two features of the genus are not taken into account by Hill and are to be added in the diagnosis: 1) proximal side convex, 2) outline of the corallum generally lobate.

\section{Petridictyum casanovai Plusquellec \& Soto,}

$$
\text { n. sp. }
$$

Figs. 5, 6, 7a, 10a

Derivatio nominis: Dedicated to Santiago Casanova i Giner, a priest who was a disciple of the Catalonian palaeontologist Dr. Bataller, for his contribution to the Palaeontology of Catalonia.

Locus typicus: Bruguers area (Gavà), Catalonian Coastal Ranges, Spain (Fig. 1).

Stratum typicum: Outcrop 4beta, upper part of the B Member in the Olorda Formation, upper Lochkovian to basal Pragian (Fig. 2).

Holotypus: specimen MGSB 73907.

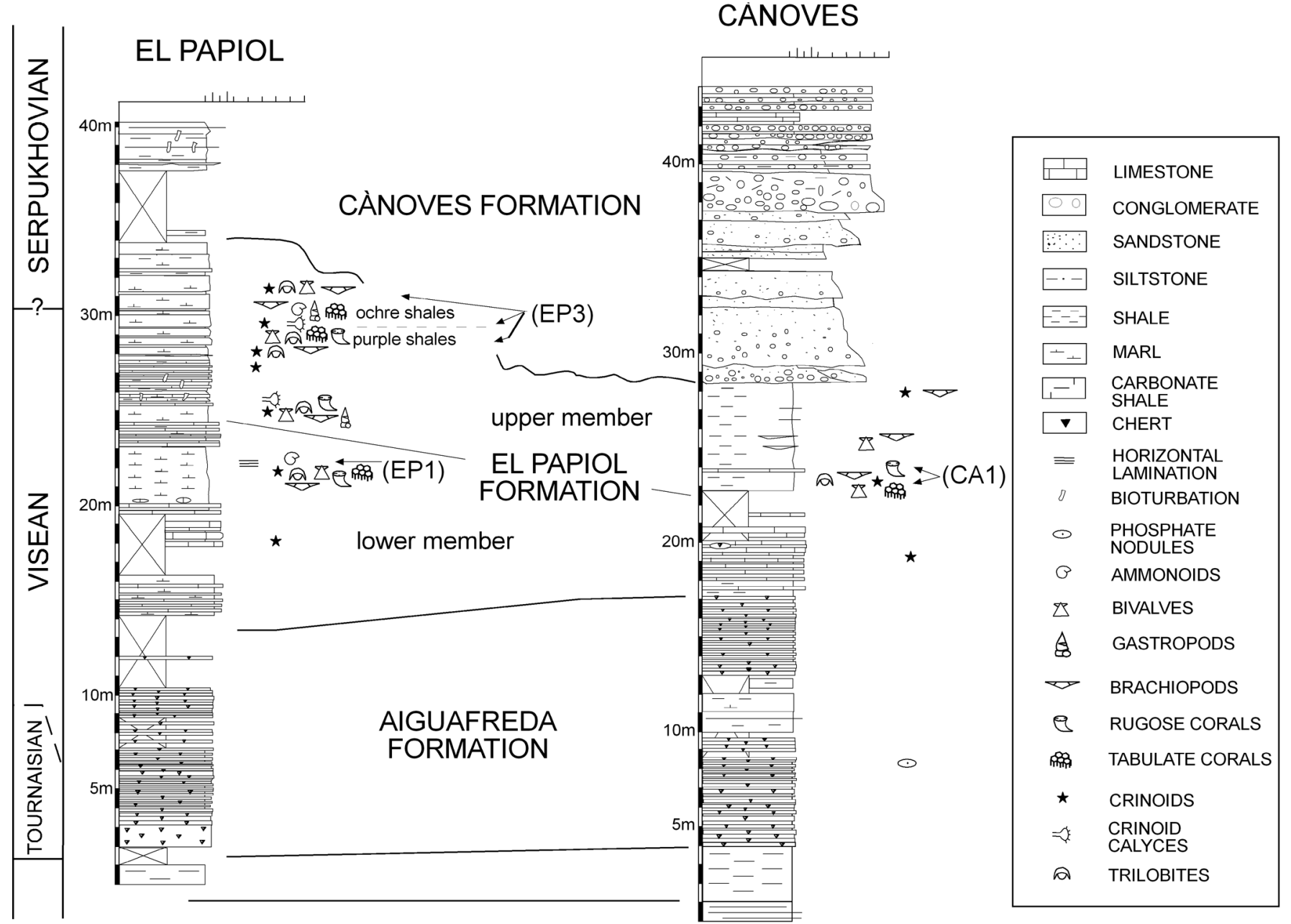

Figure 4. Stratigraphic sections from El Papiol (El Papiol 3) and Cànoves with the lithostratigraphic units used (modified from Martínez Chacón et al., 2003). The first section includes the probable setting of the palaeontological outcrop El Papiol 1. 
Material: The holotype and two other specimens (LPB 15205 and LPB 15206) coming from a locality (E of El Pintado reservoir, Valle Syncline, N Sevilla) at Ossa-Morena Zone.

Diagnosis: Small (6-7 mm) species of Petridictyum, with few corallites (5-6), flat septal ridges broader than the corresponding interseptal furrows, minor septal ridges with free proximal tip, minor and major septal ridges bearing scattered small spines, protocorallite with 3 (or 4?) major ridges, metacorallites with 4-5 major ridges, first pair of minor septal ridges well differentiated, basal pore often wide.

Description: The following description is based on the holotype, nevertheless it is validated by complementary data from OssaMorena material and some comments on these specimens.

The holotype is preserved as a natural cast, in which only the distal side is observed. Thus, the proximal side is unknown.

Distal side: The outline of the corallum is lobate and the cast of its distal side slightly convex at the calicinal bottom level (Fig. 5f). The protocorallite $\left(1_{1}\right)$ or initial cell of Beecher (1891) is surrounded by an incomplete circle of five metacorallites. The pair of metacorallites $1_{2}$ (Fig. 5 d) do not share a common wall, so the prototriade $1_{2}-1_{1}-1_{2}$ belongs to the open type (see a preliminary definition of this concept by Plusquellec in Le Menn et al., 2002: 24). In the holotype, the growth of the corallum stops before the rather late corallite 2 develops (see for better understanding Plusquellec in Le Menn et al., 2002: Fig. 3, and Beecher, 1891: pl. IX fig. 12 where the metacorallite $2_{2}$ is called «8»). This feature has no influence on the symmetry of the corallum which remains clearly bilateral with regard to the setting of the corallites.

The wall is rather thick at the calicinal bottom level, mural pores are present (at least mid wall pores alias $\mathrm{P}_{2}$ ) and can be easily distinguished from basal pores because the latter are much wider (especially between the protocorallite and the metacorallite 2 ) (Fig. 5a). These particular kinds of pores indicate a lateral type of increase and show that the first pair of metacorallites $\left(1_{2}-1_{2}\right)$ are formed from the anterior or apical side of the protocorallite, the metacorallites 2 from its latero-posterior side and the metacorallite 3 from its posterior side.

The protocorallite is more or less rhombic in outline and shows the casts of two well developed parallel interseptal furrows on both sides of the axial plane. The cast of its apex is slightly prominent (Fig. 5e); the ornamentation of the ridges area is made of scattered prints of spines.

The metacorallites are triangular $\left(1_{2}\right)$ or trapezoidal $\left(2_{1}, 3_{1}\right)$ and exhibit well differentiated casts of more or less rhopaloid interseptal furrows (Figs. 5b, c). The areas between these intersep-
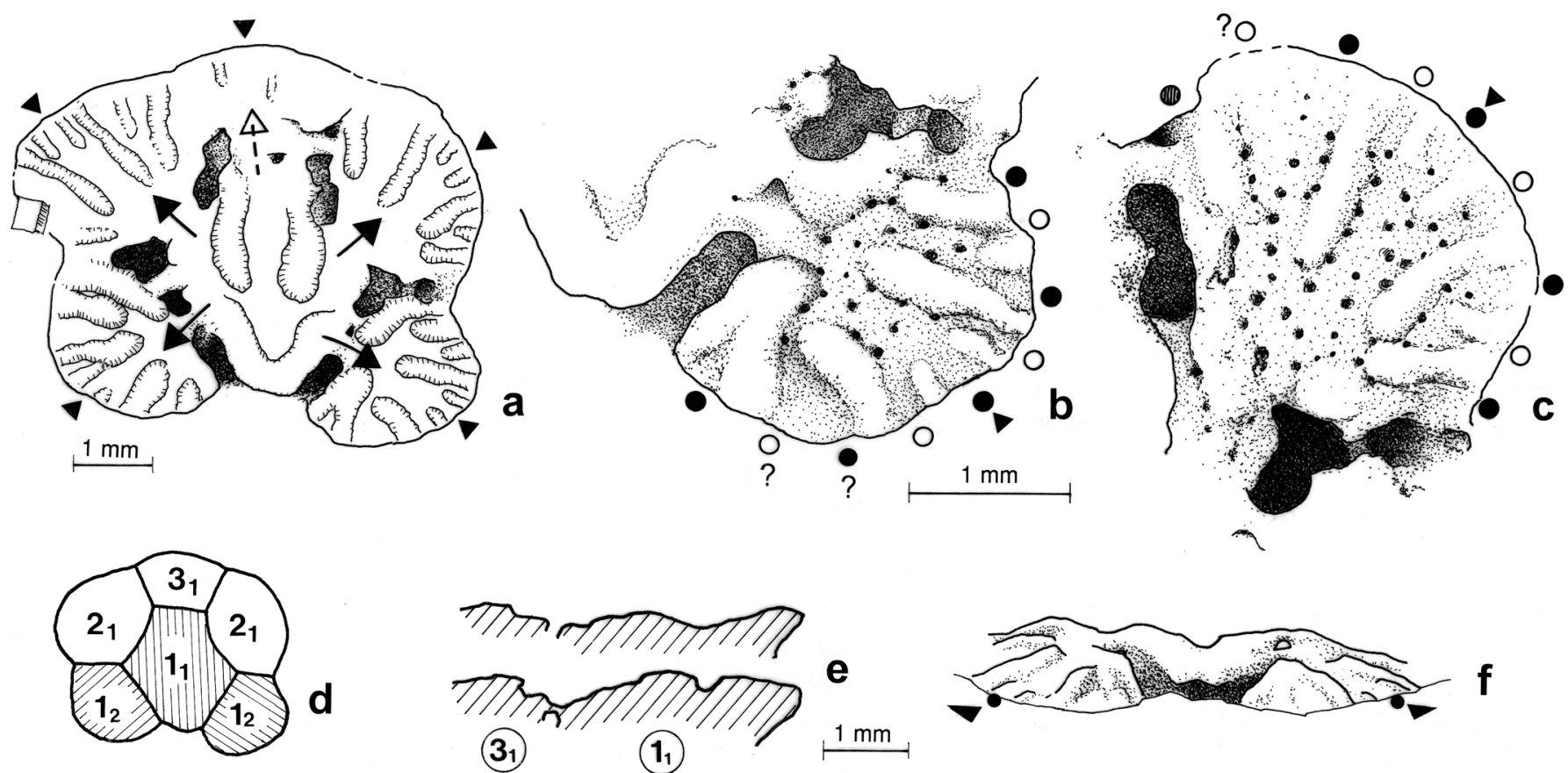

Figure 5. Petridictyum casanovai Plusquellec \& Soto, n. sp. (MGSB 73907). a, semi-schematic drawing of the natural cast of the distal side of the corallum; the narrow elongated structures represent the casts of the interseptal furrows; black triangles indicate the position of the cardinal septal ridge, black arrows show the basal pore, open arrow questionable basal pore. b, septal pattern of metacorallite $1_{2}$ right, note the casts of spines on the ridge area; black circles indicate the major septal ridges, open circles the minor septal ridges. c, septal pattern of the metacorallite 2 right; same caption as b. d, diagrammatic drawing of the corallum, prototriade $1_{1}-1_{2}$ right $-1_{2}$ left (hatched area) belonging to the open type. e, sagittal (upper drawing) and subsagittal (lower drawing) optical section passing through the protocorallite $1_{1}$ and the metacorallite $3_{1}$ and showing the outline of the calicinal botom in natural cast. f, front view of the apical part of the protocorallite and adjacent metacorallites $1_{2}$. 
tal furrows correspond to the septal ridges. They are broader than the former, flat and meet in the proximal part of the calicinal bottom. A pair of short casts of septal furrows roughly indicating the plane of bilateral symmetry of the corallite, allow us to identify the cardinal septal ridge and the first pair of septal ridges on both its sides (see Figs. 5b, c). In fact, when the calcitic skeleton is preserved, the minor and major ridges are contratingents. The interseptal furrows are devoid of ornamentation, the latter being located on the casts of the septal ridges as scattered prints of small spines (Figs. 5a, b).

Measurements: Petridictyum casanovai is a small species, the diameter of the corallum is $6 \mathrm{~mm}$ perpendicular to the plane of bilateral symmetry and 4.5 from the apex of the protocorallite to the margin of corallite 3 . Total number of corallites: $6(1+5)$. The radial diameter of the metacorallites is about $1.7 \mathrm{~mm}\left(1_{2}\right)$,

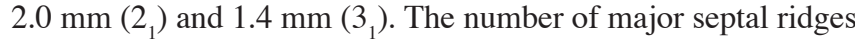
is 3 on the protocorallite and 5 on the metacorallite with probably 4 minor septal ridges.

Additional material: Some remarks on the specimens from Ossa-Morena strengthen the description of the holotype of $P$. casanovai. Two specimens (LPB 15205 and LPB 15206) (Fig. 6) were collected in locality 83 VA 20 by Racheboeuf \& Robardet (1986) in the eastern part of the El Pintado reservoir, Valle Syncline, $70 \mathrm{~km}$ north of Sevilla in the Ossa- Morena Zone. The locality 83 VA 20 is probably situated in the «Green shale with scarce nodules» of the Embalse de El Pintado Group and, according to Robardet et al. (1991: 338) belongs to the late Lochkovian or basal Pragian.

The two specimens are preserved as natural casts and one of them shows the concave cast of its proximal side with concentric lines of growth and an impression of a foreign body to which the coral was attached. Its distal side is convex (Fig. 6c) and exhibits a complete corona of five metacorallites, however the corallite $3_{1}$ had just begun to grow (Figs. 6a, d). The prototriade belongs to the contiguous type (Fig. 6d) while the other specimen (not figured, $1+5$ corallites) belongs to the open type (the basal pore of its corallite 2, is wide). The size, morphology and ornamentation of the specimens from Ossa-Morena are entirely consistent with that of Catalonia. The commensal worm Hicetes is lacking.

Discussion: The morphological features of the corallum and corallites allow an indisputable assignment to the genus Petridictyum. From its small size, its wide, flat, not free ended minor septal ridges, and its scattered spines, the specimen from Catalonia, as well as those from OssaMorena, can be easily distinguished from all other species. For example see figure 7, a comparison with the very common $P$. ex. gr. $P$. petrii (Maurer, 1874) from the Erbslochgrauwacke in Kellerwald (Schindewolf, 1959: pl. 13 figs. 4-5, pl. 14, figs. 1-2; Plusquellec \& Jahnke, 1999: pl. 1 fig. 8).

\section{Stratigraphical and palaeobiogeographical remarks:} The oldest species of the genus Petridictyum: P. tennesseensis (Amsden, 1949), is known from the «middle» Silurian of North America (Laurentia), followed, after a large gap of time, by P. lenticulare (Hall, 1874) from the New Scotland Limestone Formation, upper Lochkovian or lower Pragian (the accurate position of the Petridictyumbearing horizon is not known) of the State of New York (Laurussia). Thus, $P$. casanovai could be the first Devonian

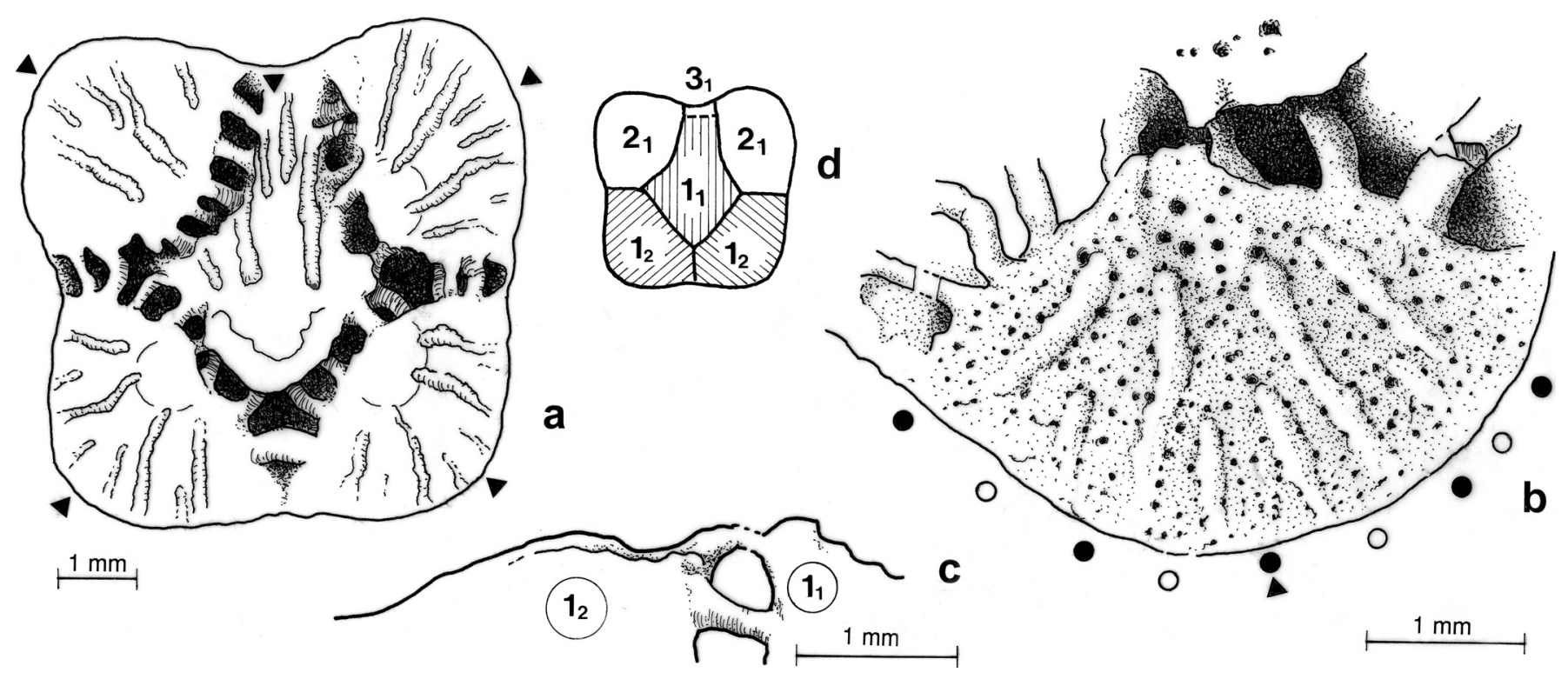

Figure 6. Petridictyum casanovai Plusquellec \& Soto, n. sp., specimen LPB 15205, Ossa-Morena, locality 83 VA 20 of Racheboeuf \& Robardet (1986), Embalse de El Pintado Group, Green shale with scarce nodules «Member», circa Lochkovian/Pragian boundary. Same caption as figure 5 for $\mathbf{a}, \mathbf{b}, \mathbf{d}$ (in $\mathbf{d}$ the prototriade belongs to the contiguous type); $\mathbf{c}$, outline of the natural cast of the metacorallite $1_{2}$ left along the cardinal ridge. 


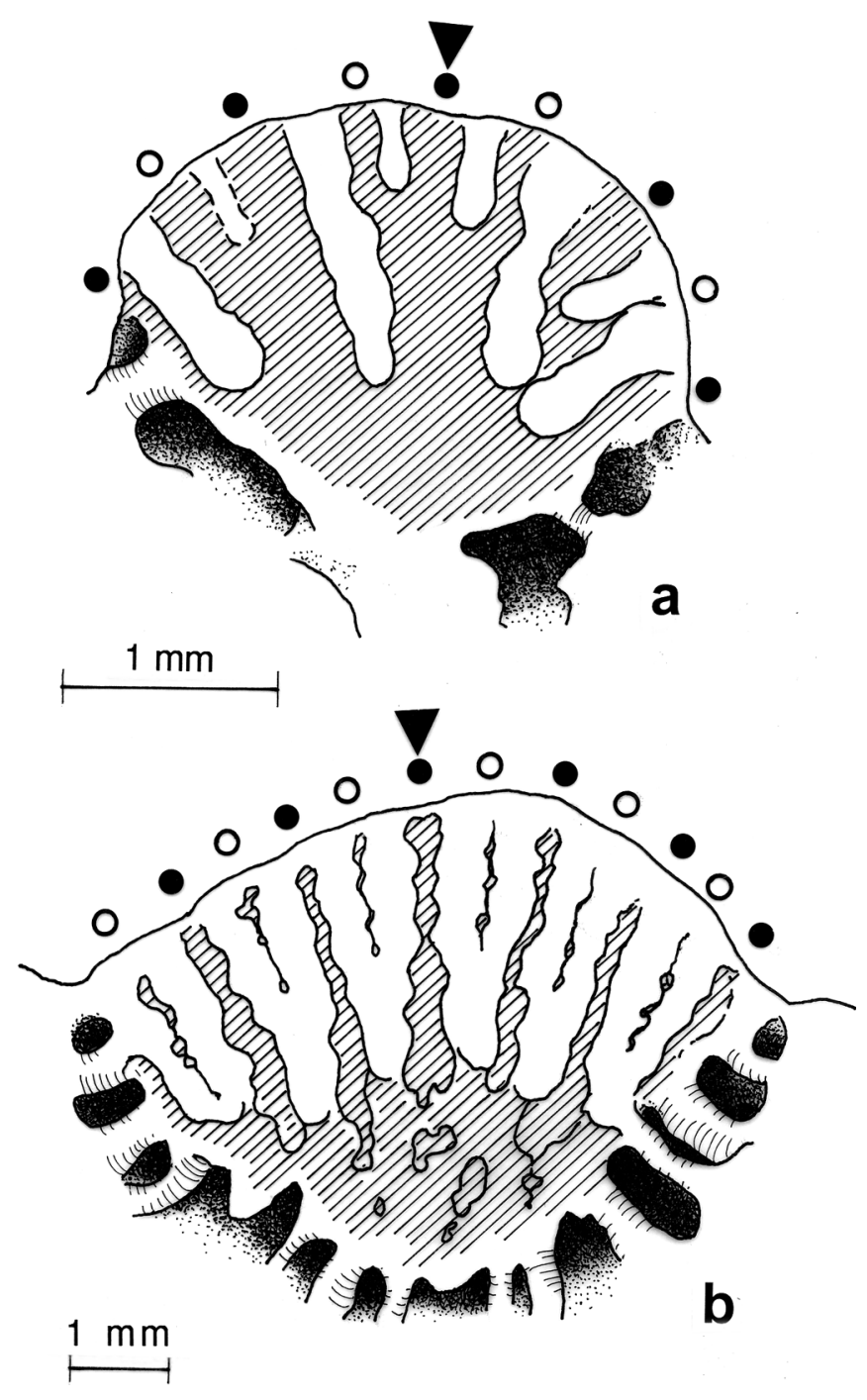

Figure 7. Comparison of the septal pattern in a, Petridictyum casanovai Plusquellec \& Soto, n. sp. (MGSB 73907) and $\mathbf{b}$, Petridictyum ex gr. petrii (Maurer, 1874) from the Erbslochgrauwacke (Göttingen 668-384); hatched area as major septal ridges. The minor ridges are broad and contratingent in $P$. casanovai, narrow and with their proximal end free in $P$. ex gr. petrii.

Petridictyum but, anyway, it is the first known occurrence of the genus on the margin of Gondwana.

\section{Subfamily Granulidictyinae Weyer, 1970 Genus Procteria Davis, 1887}

\section{Subgenus Granulidictyum Schindewolf, 1959}

Type-species: Pleurodictyum granuliferum Schlüter, 1889

Diagnosis: see Hill (1981: F567). Three features are to be added in the diagnosis: 1) proximal side generally concave, 2) proximal side granular and without concentrically wrinkled so-called epitheca, 3) pores in the basal plate.

\section{Procteria (Granulidictyum)? gavaensis \\ Plusquellec, n. sp. \\ Figs. 8, 10b, c}

Derivatio nominis: From Gavà, the name of the locus typicus.

Locus typicus: Bruguers area (Gavà locality), Catalonian Coastal Ranges, Spain (Fig. 1).

Stratum typicum: Outcrop 4beta, upper part of the B Member in the Olorda Formation, upper Lochkovian to basal Pragian (Fig. 2).

Holotypus: specimen MGSB 73908.

Material: Eight specimens, of which seven come from the horizon 4beta (MGSB 73908-73914) and one from 4Runes (MGSB 73915).

Diagnosis: Small species (diameter of corallum 8-9 mm) of Procteria (Granulidictyum)? with about 12-14 corallites, flat calicinal bottoms characterized by weakly pronounced or absent septal ridges, and numerous, very large pores in the basal plate arranged in radial rows. Intercalar corallites are probably lacking. No commensal worm Hicetes recorded.

Description: The material is preserved as natural casts. Specimens preserving the proximal side of the colonies have not been collected and all the distal sides are more or less incomplete.

Distal side: The outline of the corallum seems to be circular and the cast of the distal side is slightly concave at the calicinal bottom level (Fig. 8c).

In the central part of the corallum there is a small, six or seven sided, polygonal corallite which is probably the protocorallite. It is surrounded by trapezoidal or triangular, rarely lanceolate, metacorallites, most of them reaching the margin of the corallum. Their calicinal bottoms do not show an axial relief which is usual in Granulidictyum, but a few better preserved specimens exhibit some prints of small spines and the casts of wide and smooth septal ridges alternating with narrow interseptal ridges (Fig. 8b).

The most obvious and interesting structures that can be seen on the calicinal bottoms are the numerous sections of large pores arranged in radial rows and roughly localized on the septal ridges (Figs. 8a, $10 \mathrm{~b}$-c). These sections correspond to pores in the basal plate. In addition, neighbouring corallites are connected by mural pores (at least mid face pores) more or less arranged in longitudinal rows (Fig. 8c).

In some colonies the morphology of the calicinal bottom of one or two corallites is «erased» by the impression of a foreign body to which the corallum was attached and which is embedded in the basal plate. In this area the pores of the basal plate are necessarily lacking (Fig. 8b).

It seems that the intercalar corallites, that is to say late corallites that do not reach the basal plate, are lacking.

Measurements: The average diameters of the corallum are 8.4 $\mathrm{mm}$ (maximum) and $7.3 \mathrm{~mm}$ (minimum) for a total number of 
corallites of about 12-14. The diameter of the calicinal bottom of the central corallite is less than $1.5 \mathrm{~mm}$ while the others reach 3.5 $\mathrm{mm}$. Diameter of the pores in the basal plate is $0.25-0.30 \mathrm{~mm}$.

Discussion: Despite the lack of data on the proximal side of the corallum, the presence of numerous pores in the basal plate of the new species indicates close affinities with the genus Procteria. Moreover, the other features (lack of tabulae and not very thick wall) are consistent with the assignment to the subgenus $P$. (Granulidictyum). Nevertheless a pore-bearing basal plate is described in the genus Procterodictyum Plusquellec, 1993 and Amazonodictyum Plusquellec, 2006 nom. nud. Taking these data into account the generic/subgeneric assignment of our material has to be somewhat conditional.

Due to its small size, the lack of axial relief on the calicinal bottom, and especially the presence of large and numerous pores in the basal plate, the species of Catalonia clearly differs from all previous described species like $P$. (G.) granuliferum (Schlüter, 1889), P. (G.) соrnu (Stumm, 1950), and P. (G.) elisabetae (May, 2006; see Plusquellec \& Fernández-Martínez, 2007) as well as from Procterodictyum polentinensis Plusquellec, 1993 and Pleurodictyum
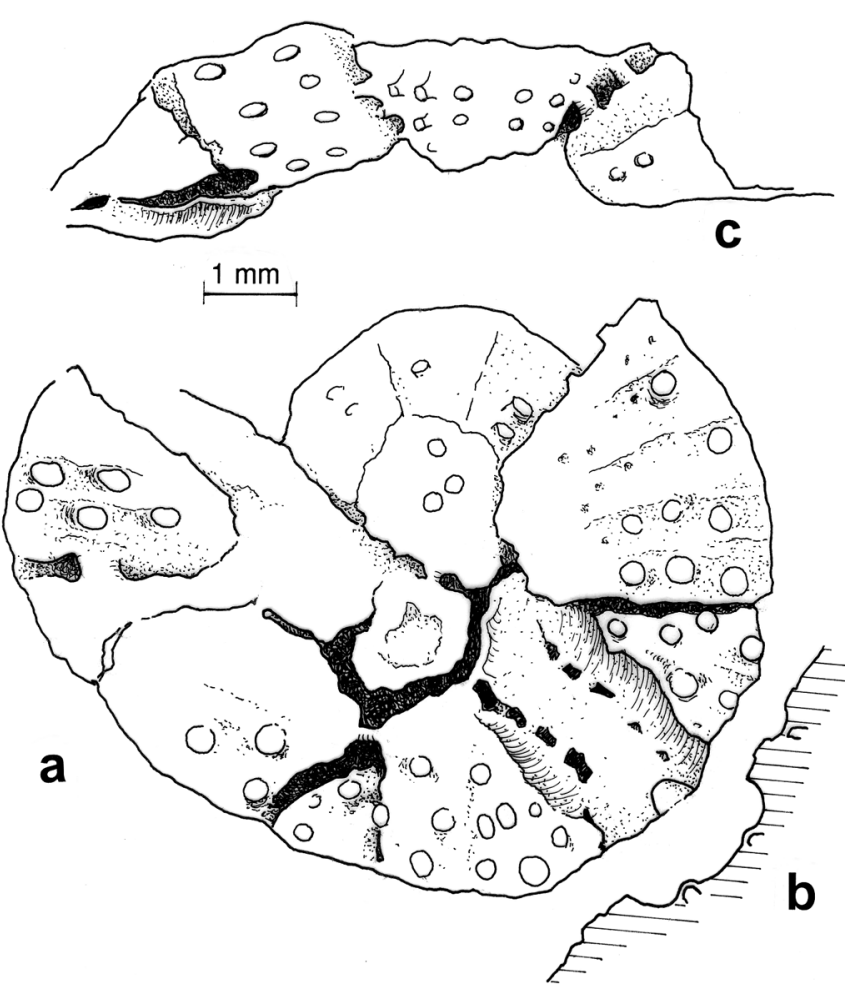

Figure 8. Procteria (Granulidictyum)? gavaensis Plusquellec, n. sp., MGSB 73915 (4Runes outcrop). a, natural cast of the distal side of the corallum. $\mathbf{b}$, section of a concave surface corresponding to a cylindrical body to which the corallum was attached. c, lateral view of the corallum. amazonicum (Katzer, 1903) (assigned to the new genus Amazonodictyum nom. nud. by Plusquellec, 2006)

Stratigraphical and paleobiogeographical remarks: If the generic/subgeneric assignment is correct, which is very likely, $P$. (G.)? gavaensis is the oldest representative of both the genus Procteria and the subgenus P. (Granulidictyum). Apart from the Catalonian data, P. (Granulidictyum) also occurs in the Lower Emsian (gronbergi or early inversus conodont Zones), Mariposas Formation d4bo, Celtiberia, Spain (Plusquellec, 2006, coll. P. Carls) and in the Lower Emsian (middle part?), Herrera Formation, Chillón-Almaden Syncline, Central Iberian Zone, Spain (Plusquellec, 2006, coll. Blachère). Thus with our present state of knowledge, it seems that the palaeogeographic origin of $P$. (Granulidictyum) could be in the Iberian part of the Ibarmaghian Domain on the NW margin of Gondwana.

Family Pseudofavositidae Sokolov, 1950

Genus Sutherlandia Cocke \& Bowsher, 1968

Type-species: Sutherlandia irregularis Cocke \& Bowsher, 1968

Diagnose: see Hill (1981: F557)

\section{Sutherlandia? sp.}

Figs. 9, 10f

Material: One specimen preserved as natural cast, MGSB 73918, from the classical locality of Cànoves (Catalonian Coastal Ranges, Spain, Fig. 1), outcrop CA1 at the upper member of the El Papiol Formation, upper Visean (Fig. 4).

Description: This small globular colony shows in its central part a bad cast of a cylindrical body (crinoid?) to which the coral was attached. The casts of the calices/corallites are of various sizes, cone-shaped, with numerous pores between the adjacent corallites and some concave upward slots corresponding to squamulae (Fig. 9).

Measurements: Corallum diameter $8 \mathrm{~mm}$ (minimum) and 10 $\mathrm{mm}$ (maximum), corallites diameter range between $2.5-2.8 \mathrm{~mm}$.

Discussion: Its preservation as a natural cast prevents the study of thin sections. Thus, the generic assignment of the specimen from Cànoves is conditional. Nevertheless, in some respects it is similar to $S$. cf. parasitica (Phillips, 1836) described in South Portugal by Tourneur (1998).

Family Palaeacidae Roemer, 1883

Genus Smythina Weyer, 1970

Type-species: Palaeacis humilis Hinde, 1896 


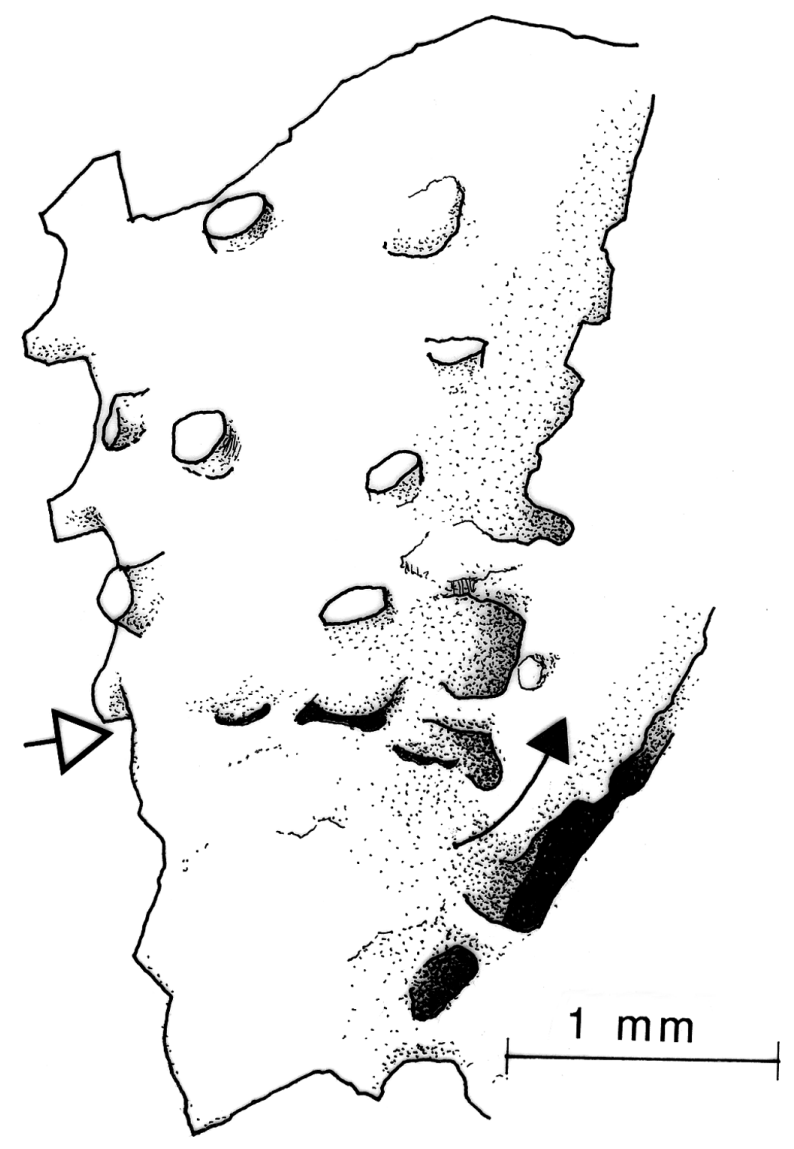

Figure 9. Sutherlandia? sp., natural cast of a large corallite showing 3 casts of squamulae (open arrow) and the cast of the basal pore between the parent corallite and the offset (black arrow).

Diagnosis: see Hill (1981: F574). See an interesting discussion on the validity of the genus in Tourneur (1998).

\section{Smythina humilis (Hinde, 1896)}

Figs. 10d-e

Synonymy and lectotype: see Tourneur (1998).

Material: Two specimens preserved in natural casts with both their proximal and distal/calicinal faces from two outcrops in the El Papiol locality, Catalonian Coastal Ranges, Spain (Fig. 1). Specimen MGSB 73919 comes from EP1 outcrop, upper part of the lower member of the El Papiol Formation, upper Visean (Fig. 4). Specimen MGSB 73920 comes from EP3 outcrop, upper part of the upper member of the El Papiol Formation, Visean/ Serpukhovian boundary.

Description: The corallum is devoid of the so-called epitheca owing to its skeleton being fully covered with live tissue, and its external surface is covered by more or less sinuous ridges sometimes broken down into granules. The proximal and central part of the external side is rather flat (Fig. 10e). The four old- est corallites, arranged in the form of a cross (Fig. 10d), diverge and become isolated with rounded calices (Fig. 10e). This setting can be completed by a late additional corallite (Fig. 10d). The natural casts of the calices show numerous narrow longitudinal furrows (= septal ridges) and casts of two kinds of pores: connective mural pores between adjacent corallites and numerous pores on the free side of the calices, going through the wall and opening on the external surface (Fig. 10d).

Measurements: Corallum diameter 9-11 mm, corallum height up to $4 \mathrm{~mm}$, corallites diameter $3.5-3.8 \mathrm{~mm}$, frequency of ridges on the external surface 6 in $2 \mathrm{~mm}$.

Discussion: The arrangement of corallites, exterior ornamentation and size of the specimens from El Papiol are similar to those of $S$. humilis described in the upper Visean by Hinde (1896) in Great Britain, by Weyer (1976) in the Rhenish Mountains and by Tourneur (1998) in South Portugal. A small additional corallite present in one of the specimens of El Papiol is an interesting structure half way between the lectotype of $S$. humilis (four large corallites) and the specimen figured by Tourneur (1998: fig. 2A) in which four large corallites alternate with four small ones.

Stratigraphic and palaeobiogeographical remarks: Prior to its discovery in Catalonia, the genus Smythina was only recorded in the southern margin of Laurussia (=Euramerica) i.e. S. humilis from Lancashire and North Devon (Hinde, 1896), Aprath in the Rhenish Mountains (Weyer, 1976) and Carrapateira-Bordeira in South Portugal Zone (Tourneur, 1998). Concerning this latter zone, Oliveira et al. (2000: 77) indicated that the «South Portugal Zone would be in close geographic continuation with southwest England, and that both regions were part of the Avalonian plate already joined to Laurussia». In addition, Tourneur (1998) had noticed the affinities of the tabulate corals of South Portugal with those of the United Kingdom, Germany and Poland during the Upper Visean.

The occurrence of Smythina in the Catalonian Coastal Ranges indicates that the genus also occurs on the northern margin of Gondwana. The Rheic Ocean was almost closed at that time and the distance between Catalonia and southern England was not great. Futhermore, the finding of Smythina near the Visean/Serpukhovian boundary is probably the earliest record of the genus.

Genus Palaeacis Haime in Milne-Edwards, 1857

Type-species: Palaeacis cuneiformis Haime in Milne-Edwards, 1857

Diagnosis: see Hill (1981: F572). Hill indicated "calices lined with? atrabeculate fibrous tissue". In fact the trabeculae are very well developed as shown by Webb (1989) and Plusquellec et al. (1990). 

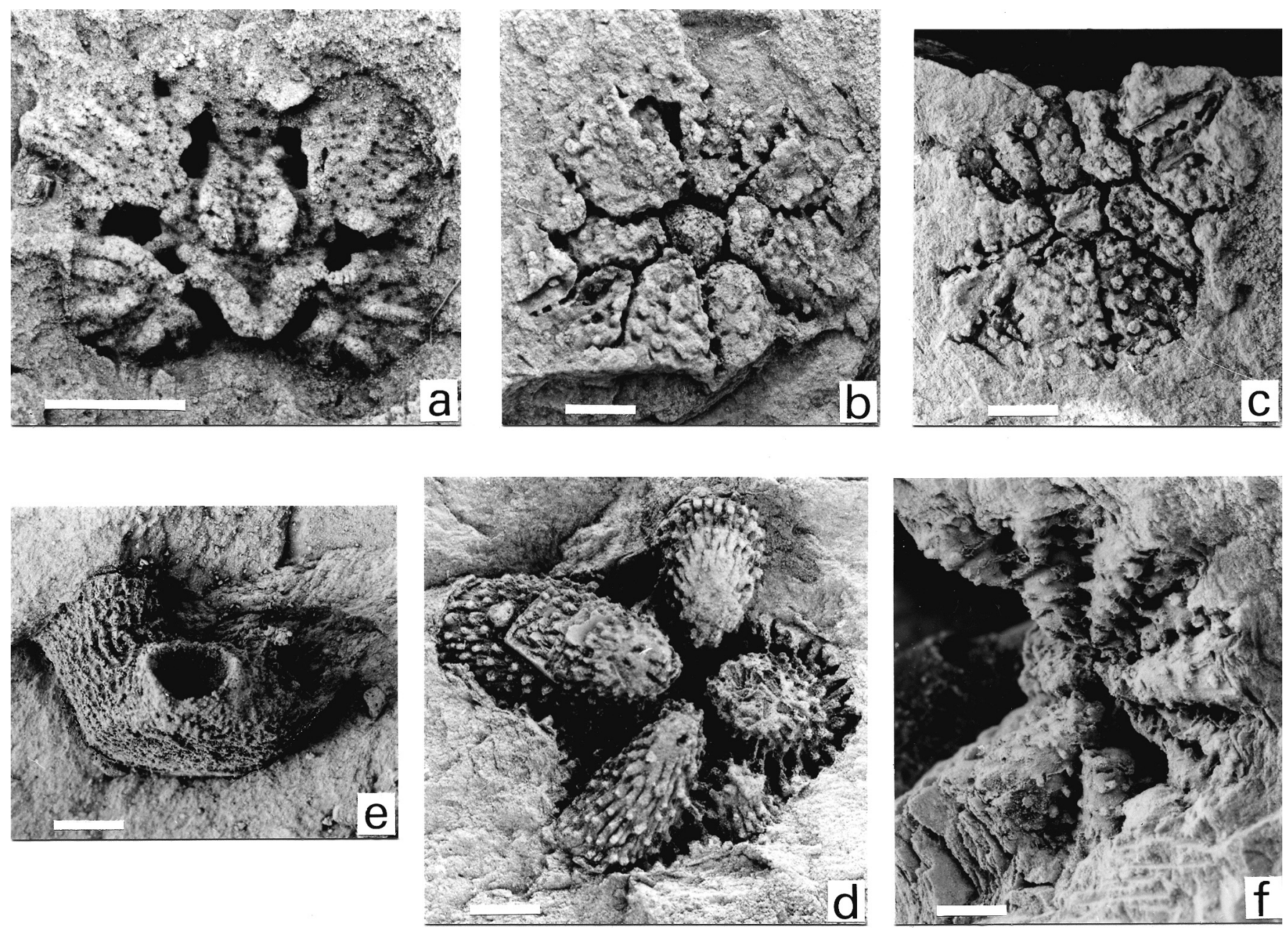

Figure 10. Devonian and Carboniferous Tabulata of Catalonia. a, Petridictyum casanovai Plusquellec \& Soto, n. sp., MGSB 73907, holotype, natural cast of the distal side of the corallum, x10. b-c, Procteria (Granulidictyum)? gavaensis Plusquellec, n. sp., natural cast of the distal side of the corallum, note in the two specimens the large and numerous casts of pores in the basal plate, x 5. b, MGSB 73908, holotype (4beta outcrop); c, MGSB 73914 (4beta outcrop). d-e, Smythina humilis Hinde, 1896, x5. d, MGSB 73920 (EP3 outcrop), natural cast of 4 large corallites forming a cross pattern, additional corallite well exposed on lower right side of the figure. e, MGSB 73919 (EP1 outcrop), side view of a latex cast of the external surface of the corallum. f, Sutherlandia? sp. MGSB 1223 (CA1 outcrop, Cànoves), natural cast of the calices, $\mathrm{x} 5$. For all figures, scale bar $=2 \mathrm{~mm}$.

\section{Palaeacis sp.}

Fig. 11

Material: One specimen preserved in natural cast MGSB 73921 from El Papiol locality, EP3 outcrop, upper part of the upper member of the El Papiol Formation, Visean/Serpukhovian boundary (Catalonian Coastal Ranges, Spain; Figs. 1 and 4).

Description: The specimen is rather incomplete, roughly wedgeshaped. Three adjacent corallites occur in a single plane and diverge from the axis at $50-60^{\circ}$ (Fig. 11). Calices are subcircular in cross section, deep and conical, and some of them are connected by mural pores (casts of) while others, tortuous, open on the external surface.

Measurements: Width $8.5 \mathrm{~mm}$, thickness $5 \mathrm{~mm}$, height more than $6 \mathrm{~mm}$, diameter of calices $2.5 \mathrm{~mm}$.

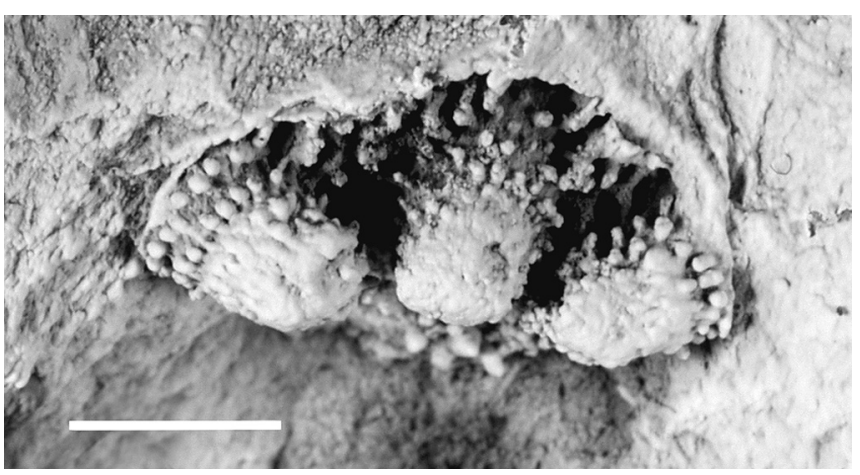

Figure 11. Palaeacis sp., MGSB 73921 (EP3 outcrop), natural cast of an incomplete corallum showing three adjacent corallites. Scale bar $=3 \mathrm{~mm}$. 
Discussion: Due to the lack of the main part of the external side, the specimen remains in open nomenclature. Nevertheless it probably belongs to the morphotype 1 of Webb (1993: fig. 11) called "Wedge-planar corallites" to which $P$. cuneiformis is assigned. The genus is common in the Mississippian but some species have been described from the Pennsylvanian (see Nudds, 1983, who summarized the occurrence of Palaeacis worlwide).

Order AULOPORIDA Sokolov, 1950

Family Pyrgiidae de Fromentel, 1861

\section{Genus Cladochonus McCoy, 1847}

Type-species: Cladochonus tenuicollis McCoy, 1847

Diagnosis: see Lafuste \& Tourneur (1992: 26).

\section{Cladochonus sp.}

Fig. 12

Material: One slab with some fragments of branches preserved in natural casts, MGSB 73922, from El Papiol locality, EP3 outcrop, upper part of the upper member of the El Papiol Formation, Visean/Serpukhovian boundary (Catalonian Coastal Ranges, Spain; Figs. 1 and 4).

Description: The corallites are pipe-like, slender, and the zigzag pattern is not clearly shown. One of the corallites shows the cast of a diaphragm separating parental and daughter corallites on the dorsal side of the calice; it bears the prints of three or four small parallel ridges alternating with rows of up to four prints of openings (?). This structure is close to the one described by Stasinska (1982) in $C$. tenuicollis but with fewer rigdes. The distal part of the calice exhibits the casts of very wide and flat septal ridges only seen thanks to the presence of narrow rows of very small pits (Fig. 12).

Measurements: The distance between two successive corallites seems to be up to $26 \mathrm{~mm}$ (!), maximum diameter of corallite 5.5 $\mathrm{mm}$, width of septal ridges $0.5 \mathrm{~mm}$.

Discussion: The distance between corallites seems unusual and thus the specimens of Catalonia differ from those of the upper Visean of Portugal (Tourneur, 1998) and Rhenish Mountains (Weyer, 1976).

\section{PALAEOECOLOGICAL REMARKS}

Neuman (1988) stated that corals have two main life strategies: Most of them are sessile and live attached to hard substrates during their entire lives. But some others have an attached, usually short, juvenile phase, and then they are freeliving. Some of these freeliving corals are loose, potentially mobile forms and thus they are capable of lateral migration, righting of the corallum after it has been overturned, vertical movement through sediment and/ or active resistence to being buried under soft sediment.

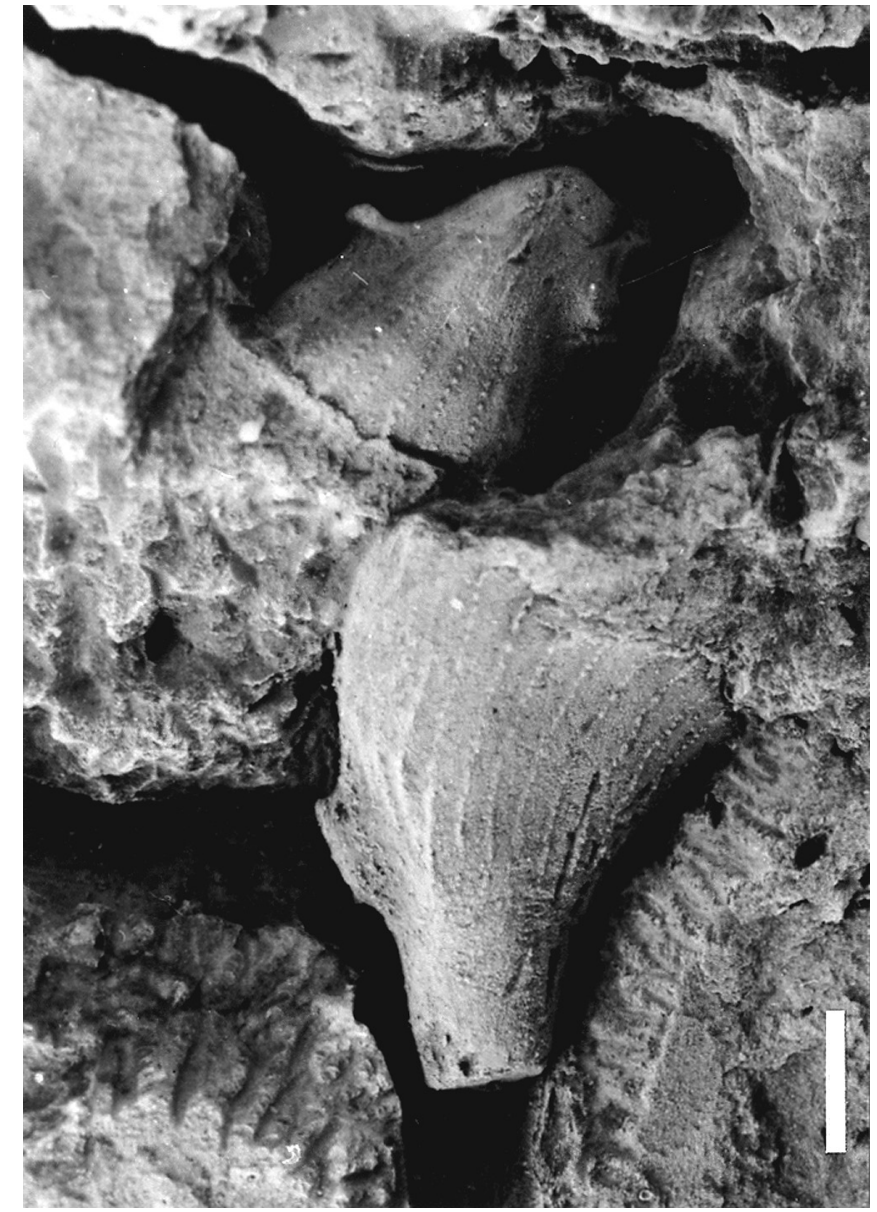

Figure 12. Cladochonus sp., MGSB 73922 (EP1 outcrop), natural cast of a calice showing the narrow «dotted» interseptal furrows, $x 5$. Scale bar $=2 \mathrm{~mm}$.

Studies on the automobility in tabulate corals are scarce. Among others, Plusquellec et al. (1990) considered the genus Procteria to be a mobile coral; Plusquellec (1993) indicated probable automobility in the tabulate Procterodictyum Plusquellec, and Webb (1994) suspected lateral migration in the carboniferous coral Palaeacis Haime.

More recently, Plusquellec et al. (1999) indicated five morphological characters which appear to be important indicators of automobility. According to these authors, three of the six taxa described in this paper could have morphologies well adapted to automobility: Procteria (Granulidictyum)? gavaensis, Smythina humilis and Palaeacis sp.

From a palaeoecological point of view, Webb (1994: 231) indicated that extant mobile corals live on soft substrates and Plusquellec et al. (1999: 993) stated that all Palaeozoic taxa that are considered to be automobile appear to have occupied muddy to silty bottoms. This is also the case for the Catalonian corals described in this paper. Thus, Procteria (Granulidictyum)? gavaensis come from layers of carbonate shales and the Carboniferous taxa (Smythina humilis and Palaeacis sp.) were collected 
in the El Papiol Formation, in beds mainly composed of shales and marls.

On the other hand Sutherlandia? sp. (from El Papiol Formation, CA1 outcrop), shows in its central part a probable cast of a cylindrical body to which the coral was attached. Tourneur (1998) studied a Visean fauna of tabulate corals composed by the genera Sutherlandia, Cladochonus and Smythina, in which the first two genera were attached to and encircling crinoid stems. This life strategy would have been advantageous if the water were turbid, and therefore could also indicate a soft muddy substrate (see Tourneur's study, 1998 for more details).

\section{CONCLUSIONS}

The study of the Olorda Formation in the Bruguers section has allowed us to compare this section with that already described in the type locality Santa Creu d'Olorda. As a result of this comparison it has been established that:

1) Part of A Member of the Olorda Formation in Bruguers can be correlated with the lower part of B member of the same formation in Santa Creu d'Olorda, where the sequence is more condensed.

2) B Member of the Olorda Formation in Bruguers is composed of shales with some carbonate beds, while in the type section of the Olorda Formation (Santa Creu d'Olorda) limestones prevail.

The studied Devonian tabulate corals from Bruguers can not be assigned to Pleurodictyum selcanum Giebel, 1858 , which is the only tabulate coral species noted up to now in the Olorda Formation, because it refers to a badly defined species, about which little is known and possibly not assigned to the Pleurodictyum genus. On the contrary, this material corresponds to two new taxa of Petridictyum and Procteria (Granulidictyum)? These findings represent the first identification of both taxa in the Nord-Gondwana margin. The identification of $P$. (Granulidictyum)? is very important because it suggests a Nord-Gondwanic origin for this taxon.

A small fauna of tabulate corals from the Visean of South Portugal, composed by the genera Sutherlandia Cocke \& Bowsher, 1968, Smythina Weyer, 1970 and Cladochonus McCoy, 1847 has been studied by Tourneur (1998). This assemblage is also known in the upper Visean of Lancashire and North Devon (Hinde \& Fox, 1895; Hinde, 1896), of Aprath in Renish Mountains (Weyer, 1976) and of Poland (Cracovia area, with somewhat different composition, see Tourneur, 1998 for further details). In the same way, these three genera have been also recorded in the Catalonian Coastal Ranges, even though they have been found in different outcrops: Smythina humilis in EP1 and EP3 outcrops, Sutherlandia? sp. in CA1 site and Cladochonus sp. in EP3 outcrop.

\section{ACKNOWLEDGEMENTS}

This study was supported by the Spanish projects CGL200503715/BTE, CGL2006-04554/BTE and CGL2006-06401/BTE funded by the "Ministerio de Educación y Ciencia" and "Fondo Europeo de Desarrollo Regional (FEDER)". It is a contribution to the PICG 499: "Devonian land-sea interaction: Evolution of Ecosystems and climate" (DEVEC). We are grateful to Mr. Ramón Mañé for his valuable advice on material collecting.

\section{REFERENCES}

Alberti, G.K.B. 1980. Neue Arten der Nowakiidae (Dacryoconarida) aus dem Unterdevon von Algerien. Senckenbergiana Lethaea, 61, 13-16.

Alberti, G.K.B. 1993. Dacryoconaride und homoctenide Tentaculiten des Unter- und Mittel-Devons I. Courier Forschungsinstitut Senckenberg, 158, 1-129.

Almera, J. 1891. Mapa geológico y topográfico de la provincia de Barcelona. Región primera o de contornos de la Capital. E. 1:40000. Diputación Provincial de Barcelona.

Almera, J. 1898a. Compte-rendu de l'excursion du mardi 4 Octobre, à Castellbisbal et à Papiol. Bulletin de la Société géologique de France, ser. 3, 26, 766-788.

Almera, J. 1898b. Compte-rendu de l'excursion du mercredi 5 Octobre, à Gavà, Begas et Vallirana. Bulletin de la Société géologique de France, ser. 3, 26, 789-800.

Almera, J. 1900. Mapa geológico y topográfico de la provincia de Barcelona. Región I. E. 1:40000, $2^{\mathrm{a}}$ edición. Diputación Provincial de Barcelona.

Amsden, T.W. 1949. Stratigraphy and Paleontology of the Brownsport Formation (Silurian) of Western Tennessee. Peabody Museum of Natural History, 5, 1-135.

Anadón, P., Julivert, M. \& Sáez, A. 1985. Aportación al conocimiento del Carbonífero de las Cadenas Costeras Catalanas. In: X Congrès International de Stratigraphie et de Géologie du Carbonifère, Madrid, 1983. Instituto Geológico y Minero de España, Madrid, 1, 99-106.

Bardashev, I.A. 1989. Novye listovidnye konodonty iz nizhnego devona tsentral'nogo Tadzhikistana (New conodonts from Lower Devonian of central Tadghikistan). Dushanbe, Akademiya Nauk Tadzhikskoi SSR Institut Geologii, 5-14.

Barrande, J. 1852. Système Silurien du centre de la Bohême. 1. Trilobites. Prague - Paris, 1-935.

Barrande, 1867. Système Silurien du centre de la Bohême, le partie, vol. III. Classe des Mollusques. Ordre des Ptéropodes. Prague, 1-179.

Barrois, Ch. 1892. Sur le terrain dévonien de la Catalogne. Annales de la Société Géologique du Nord, 12, 47-61.

Barrois, Ch. 1893. Observaciones sobre el terreno Silúrico de los alrededores de Barcelona. Boletín de la Comisión del Mapa Geológico de España, 19, 245-260.

Beecher, C.E. 1891. The development of a Paleozoic Poriferous Coral. Transactions of the Connecticut Academy, $\mathbf{8}$, 207-214.

Bischoff, G. \& Sannemann, D. 1958. Unterdevonischen Cono- 
donten aus dem Frankenwald. Notizblatt des Hessischen Landesamtes für Bodenforschung, 86, 87-110.

Bouček, B. 1964. The tentaculites of Bohemia. Publication of Czechoslovakian Academy of Sciences, Praha, 1-215.

Boucot, A.J. 1975. Evolution and extinction rate controls. Developments in Palaeontology and Stratigraphy, 1, Elsevier Scientific Publishing Co. Amsterdam, 1-427.

Chlupáč, I. 1995. Evaluation of some Devonian Standard boundaries. Nova Acta Leopoldina, 291 (71), 41-52.

Chlupáč, I. \& Kukal, Z. 1986. Reflection of possible global Devonian Events in the Barrandian Area, C. S. S. R. In: Global Bio-Events (Ed. O. Walliser). Lecture Notes in Earth Sciences, 8, 169-179

Chlupáč, I. \& Oliver, W.A., Jr. 1989. Decision on the Lochkovian-Pragian Boundary Stratotype (Lower Devonian). Episodes, 12, 109-113.

Chlupáč, I., Ferrer, E., Magrans, J., Mañé, R. \& Sanz, J. 1997. Early Devonian eurypterids with Bohemian affinities from Catalonia (NE Spain). Batalleria, 7, 9-21.

Cocke, J.M. \& Bowsher, A.L. 1968. New tabulate genus Sutherlandia (Coelenterata, Anthozoa) from Pennsylvanian of Oklahoma and Kansas. University of Kansas Paleontological Contributions, 33, 1-8.

Davis, W. J. 1887. Kentucky Fossil Corals - a monograph of the Fossil Corals of the Silurian and Devonian Rocks of Kentucky, Part 2. Kentucky Geological Survey, 13 (4), 1-13.

Ferrer, E., Magrans, J. \& Mañé, R. 1992. Euriptèrids (merostomats) del Devonià inferior de Bruguers (Gavà) i Santa Creu d'Olorda (Sant Feliu de Llobregat). I Trobada d'estudiosos de Garraf, Sitges 1989. Monografías, 19, 3338, Diputació de Barcelona, Servei de Parc Naturals.

Flajs, G. 1967. Conodontenstratigraphische Untersuchungen im Raum von Eisenerz, Nördliche Grauwackenzone. Mitteilungen der Geologischen Gesellschaft in Wien, 59, 157-212.

García-López, S., Julivert, M., Soldevilla, J., Truyols-Massoni, M. \& Zamarreño, I., 1990. Biostratigrafía y facies de la sucesión carbonatada del Silúrico Superior y Devónico Inferior de Santa Creu d'Olorda (Cadenas Costeras Catalana, NE de España). Acta Geològica Hispànica, 25, 141-168.

Giebel, C. 1858. Die Silurische Fauna des Unterharzes nach Herren C. Bischof's Sammlung. Abhandlungen des Naturwissenschaftlichen Vereinen für die Provinz Sachsen und Thüringen in Halle, 1, 1-70.

Greiling L. \& Puschmann, H. 1965. Die Wende SiluriumDevon aus St. Creu d'Olorde bei Barcelona (Katalonien). Senckenbergiana Lethaea, 45, 453-457.

Gutiérrez-Marco, J.C., Ferrer, E., Robardet, M. \& Roqué Bernal, J. 1999. Graptolitos multirramosos del Devónico de las Cadenas Costeras Catalanas (noroeste de España). Temas Geológico-Mineros ITGE, 26, 610-617.

Hall, J. 1874. Descriptions of Bryozoa and Corals of the Lower Helderberg Group. Annual Report on the New York State Museum of Natural History, 26, 93-116.

Hill, D. 1981. Part F. Coelenterata. Supplement 1. Rugosa and Tabulata (Volume 2). In: Treatise on Invertebrate Paleon- tology (Eds. R.C. Moore, R.A. Robinson, \& C. Teichert). Geological Society of America, Boulder, Colorado and University of Texas, Lawrence, F430-F762.

Hinde, G.J. 1896. Description of new fossils from the Carboniferous limestone. II. On Palaeacis humilis sp. nov., a new perforate coral, with remarks on the genus. Quaterly Journal of the Geological Society of London, 52, 440-451.

Hinde, G.J. \& Fox, H. 1895. On a well-marked horizon of Radiolarian rocks in the Lower Culm Measures of Devon, Cornwall, and West Somerst. Quarterly Journal of the Geological Society of London, 52, 609-668.

Julivert, M. \& Durán, H. 1990. Paleozoic stratigraphy of the Central and Northern part of the Catalonian Coastal Ranges (NE Spain). Acta Geològica Hispànica, 25, 3-12.

Julivert, M., Durán, H., Rickards, R.D. \& Chapman, A.J. 1985. Siluro-Devonian graptolite stratigraphy of the Catalonian Coastal Ranges. Acta Geològica Hispànica, 20, 199-207.

Julivert, M., Durán, H., García-López, S., Truyols-Massoni, M. \& Villas, E. 1986. The Paleozoic pre-Carboniferous sequence in the Catalonian Coastal Ranges (NE Spain) and its faunas. IGCP Project n. 5, Final Meeting (Sardinia), Abstracts, 31-37.

Julivert, M., Durán, H., García-López, S., Gil-Ibarguchi, I., Truyols-Massoni, M. \& Villas, E. 1987. Pre-Carboniferous rocks in the Catalonian Coastal Ranges: volcanism, stratigraphic sequence and fossil content. In: Pre-Variscan events in the Alpine-Mediterranean mountain belts (Eds. H. W. Flügel, F.P. Sassi \& P. Grecula). Mineralia Slovaca, Monography, 313-322.

Katzer F. 1903. Grundzüge der Geologie des Unteren Amazonasgebietes (des Staates Parà in Brasilien). Max Weg, Leipzig, 1-296.

Kullmann, J., Magrans, J., Ferrer, E. \& Abad, A. 2001. Primer hallazgo del género Dombarites (Cephalopoda, Ammonoidea) del Carbonífero inferior en El Papiol (Cataluña, España). Batalleria, 10, 5-8.

Lafuste, J. \& Tourneur, F. 1992. Révision des espèces de Cladochonus McCoy, 1847 (Tabulata) décrites dans le Frasnien de la Belgique par Lecompte en 1939. Bulletin de l'Institut Royal des Sciences Naturelles de Belgique, 62, 23-41.

Le Menn, J., Gourvennec, R., Plusquellec, Y., Piçarra, J.M., Pereira, Z., Robardet, M. \& Oliveira, J.T. 2002. Lower Devonian benthic faunas from the Barrancos area (Ossa Morena Zone, Portugal) and their paleobiogeographic affinities. Communicações do Institituto Geológico e Mineiro, 89, 19-38.

Lukes, P. 1982. Nowakia sororcula sp. n., a new dacryoconarid tentaculite from the Lochkovian-Pragian boundary beds of barrandian. Casopis pro Mineralogii a Geologii, 27, 409-411.

Magrans, J. \& Ferrer, E. 2006. Trilobits i dacrioconàrids de Bruguers (Gavà). Butlletí dels Amics del Museu Geològic del Seminari de Barcelona, 47, 10-11.

Martínez Chacón, M.L., Winkler Prins, C. F., Sanz López, J., Ferrer, E. \& Magrans, J. 2003. Braquiópodos misisípicos 
de los alrededores de Barcelona (Cadenas Costeras Catalanas, NE de España). Revista Española de Paleontología, 18, 189-204.

Maurer F. 1874. Paläontologische Studien im Gebiete des rheinischen Devon. Neues Jahrbuch für Mineralogie, Geologie und Paläontologie, 453-459.

May, A. 2006. Micheliniidae and Cleistoporidae (Antohozoa, Tabulata) from the Devonian of Spain. Bulletin of Geosciences, 81, 163-172.

McCoy, F. 1847. On the fossil botany and zoology of the rocks associated with the coal of Australia. Annals and Magazine of Natural History, London, 20, 145-157, 226236, 298-312.

Milne-Edwards, H. 1857. Histoire naturelle des coralliaires ou polypes proprement dits. Vol. 1. Roret, Paris, 1-326.

Neuman, B.E.E. 1988. Some aspect of life strategies if early Palaeozoic rugose corals. Lethaia, 21, 97-114.

Nudds, J.R. 1983. The Carboniferous Coral Palaeacis in Ireland. Palaeontology, 26, 211-225.

Oliveira, J.T., Piçarra, J.M., Pereira, Z., Meireles, C., Couto, H., Korn, D., Robardet, M., Le Menn, J., Gourvennec, R. \& Romano, M. 2000. Silurian to Carboniferous successions of the SW Iberian Massif (Portugal). Livro-guia da VIII International Field Meeting of IGCP 421, Universidade de Évora, 1-153.

Perner, J. 1899. Études sur les graptolites de Bohême. IIIième Partie. Monographie des graptolites de l'Étage E. Section b Palaeontolographica Bohemiae, R. Gerhard, Prague, 1-24.

Phillips, J. 1836. Illustrations of the geology of the SiluroDevonian sediments of the Tyers area, Gippsland, Victoria. Royal Society of Victoria, Proceedings, 75, 124-246.

Plusquellec Y. 1993. Un Tabulé pleurodictyforme «biface», Procterodictyum n. gen. (Emsien du Nord Gondwana). Geologica et Palaeontologica, 27, 103-117.

Plusquellec, Y. 2006. Histoire naturelle des pleurodictyformes (Cnidaria, Tabulata) du Massif armoricain et des régions maghrébo-européennes principalement. Unpublished thesis, UBO, Brest, 1-73.

Plusquellec, Y. \& Fernández-Martínez, E. 2007. Comments on the paper by A. May "Micheliniidae and Cleistoporidae (Anthozoa, Tabulata) from the Devonian of Spain". Bulletin of Geosciences, 82, 85-89.

Plusquellec, Y. \& Jahnke, H. 1999. Les tabulés de l'Erbslochgrauwacke (Emsien inférieur du Kellerwald) et le problème des affinités paléogéographiques de l'allochtone «Giessen-Harz». Abhandlungen der Geologischen Bundesanstalt, 54, 435-451.

Plusquellec, Y., Lafuste, J. \& Webb, G.E. 1990. Organisation de type tétracoralliaire des rides septales de Palaeacis (Cnidaria, Carbonifère). Lethaia, 23, 385-397.

Plusquellec, Y., Webb, G.E. \& Hoeksema, B.W. 1999. Automobility in tabulata, rugosa, and extant scleractinian analogues: stratigraphic and paleogeographic distribution of Paleozoic mobile corals. Journal of Paleontology, 73, 985-1001.

Puschmann, H. 1968a. Stratigraphische Untersuchungen im
Paläozoikum des Montseny (Katalonien/Spanien). Geologische Rundschau, 57, 1066-1088.

Puschmann, H. 1968b. La série paléozoique du massif du Montseny (Catalogne, Espagne du Nord-Est). Compte Rendu de la Academie des Sciences, Paris, 216, 657-659.

Racheboeuf, P.R. \& Robardet, M. 1986. Le Pridoli et le Dévonien inférieur de la Zone d'Ossa-Morena (Sud-Ouest de la Péninsule ibérique). Étude des Brachiopodes. Geologica et Paleontologica, 20, 11-37.

Racheboeuf, P.R., Ferrer Batet, E. \& Magrans, J. 1993. Un nouvel assemblage faunique du Dévonien inférieur de Catalogne (NE de 1'Espagne). Treballs del Museu de Geologia de Barcelona, 3, 5-18.

Richter, R. 1854. Thüringische Tentaculiten. Zeitschrift der Deutschen Geologischen Gesellschaft, 6, 275-290.

Robardet, M., Groos-Uffenorde, H., Gandl, J. \& Racheboeuf, P.R. 1991. Trilobites et Ostracodes du Dévonien inférieur de la Zone d'Ossa-Morena (Espagne). Geobios, 24, 333-348.

Schindewolf, O.H. 1959. Würmer und Korallen als Synöken. Zur Kenntniss der Systeme Aspidosiphon/Heteropsammia und Hicetes/Pleurodictyum. Abhandlungen der Mathematisch-Naturwissenschaftlichen Klasse, 6, 1958, 259-327.

Schlüter, C. 1889. Anthozoen des Rheinische Mittel Devon. Abhandlungen Geologische Specialkarte von Preussen und den Thüringischen Staaten, VIII, 4, 1-207.

Schriel, W. 1929. Der geologische Bau des Katalonischen Küstengebirges zwischen Ebromündung und Ampurdan. Abhandlungen der Gesellschaft der Wissenchaften zu Göttingen, mathematisch-physikalische Klasse, N.F., 14, 62-141.

Stasinska, A. 1982. Colony structure and systematic assignment of Cladochonus tenuicollis McCoy, 1847 (Hydroidea). Acta Palaeontologica Polonica, 27, 59-64.

Stumm, E. C. 1950. Corals of the Devonian Traverse Group of Michigan. Part III, Antholites, Pleurodictyum, and Procteria. Contributions from the Museum of Paleontology, The University of Michigan, 8, 205-214.

Tourneur, F. 1998. Tabulés dinantiens du Sud-Ouest du Portugal. Geologica Bélgica, 1, 33-40.

Valenzuela-Ríos, J.I. \& García-López, S. 1998. Using conodonts to correlate abiotic events: an example from the Lochkovian (Early Devonian) of NE Spain. In: Proceedings of the Sixth European Conodont Symposium (ECOS VI) (Ed. H. Szaniawski). Palaeontologia Polonica, 58, 191-199.

Valenzuela-Ríos, J.I. \& Murphy, M.A. 1997. A new zonation of middle Lochkovian (Lower Devonian) conodonts and evolution of Flajsella n. gen. (Conodonta). In: Paleozoic sequence Stratigraphy, bioestratigraphy, and biogeography: studies in Honor of J. Granville ("Jess") Johnson (Eds. G. Klapper, M.A. Murphy \& J.A. Talent). Geological Society of America, Special Paper, 321, 131-144.

Webb, G.E. 1989. Skeletal structure and microstructure in Visean Palaeacis from Queensland. Memoir of the Association of Australasian Palaeontologists, 8, 199-206.

Webb, G.E. 1993. Skeletal microstructure and mode of attachment in Palaeacis species (Anthozoa: Tabulata) from 
the Mississippian and Pennsylvanian of Northeastern Oklahoma and Northwestern Arkansas. Journal of Paleontology, 67, 167-178.

Webb, G.E. 1994. Benthic auto-mobility in discoid Palaeacis from the Pennsylvanian of the Ardmore Basin, Oklahoma. Journal of Paleontology, 68, 223-233.

Weyer, D. 1970. Granulidictyum Schindewolf, 1959 (Anthozoa, Tabulata) im Unterdevon des Thüringer Schiefergebirges. Geologie, 19, 1115-1121.
Weyer, D. 1976. Eine bemerkenswerte Cladochonus-Kolonie (Anthozoa, Tabulata) aus dem Kulm-Tonschiefer (Unterkarbon, Obervisé) von Aprath im Rheinischen Schiefergebirge. Zeitschrift der geologischen Wissenschaften Berlin, 4, 1515-1530.

Manuscrito recibido: 27 de Marzo, 2006 Manuscrito aceptado: 3 de Septiembre, 2007 